\title{
Participatory action research and co-researching as a tool for situating youth knowledge at the centre of research
}

\author{
Staci B. Martin* - Portland State University, USA \\ Jessica H. Burbach, Lulis Lares Benitez and Irisa Ramiz - Portland YouthBuilders, \\ USA
}

\begin{abstract}
Too often youth from vulnerable communities see themselves talked about in academic research, but are rarely involved as co-researchers or co-authors of research. The purpose of this article is to share our reflections on engaging youth, their experiences and their perspectives on the multi-levels of impact of participatory action research methodologies, such as community-based action research or youth participatory action research. This article discusses more broadly how our participatory methodologies have impacted our co-researchers and ourselves. In it, we provide additional details about our past research projects, as well as theorizing those details in terms of how critical theory serves as a tool within participatory methodologies. We reflect on the experiences engaging participatory methodologies in two different contexts and examine the collective impacts, comparing and contrasting the findings. We draw on our field research: one researcher worked with co-researchers from Kakuma Refugee Camp, Kenya, and the other worked alongside youth co-researchers from an alternative secondary school in the USA. Two of our co-authors are also co-researchers, and they offer a deeper insight into how these methodologies impacted their lives.
\end{abstract}

Keywords: community-based action research, youth participatory action research, co-researching, refugee education, alternative high school, critical hope

'It's not your guys' story, you guys didn't live in it. I'm not you ... it's like you're trying to speak your opinion on a road you never walked before.' Olivia, participant

The experiences of vulnerable populations have largely been interpreted through the researchers' perspective, voice and analysis. Their voices have been historically absent in traditional social science research or the studies have been about them (Groundwater-Smith and Downes, 1999). There is a growth of participatory action research (PAR) methodologies that have chosen to include participants' voices because of this gap. Researchers are applying these approaches because certain populations are over-researched (Bengtsson and Bartlett, 2011; Sukarieh and Tannock, 2013) and participants' knowledge is limited in the analysis and representation at conferences and papers (Fenge et al., 2011; Castleden et al., 2012; Martin and Umubyeyi, 2019).

As a result, more researchers are interested in applying PAR that is led by, for and researched with vulnerable communities and that accepts experiences as legitimate sources of knowledge (Solórzano and Yosso, 2009; Smith, 2012). When PAR is applied, vulnerable communities can understand the research process, why research is needed and ultimately how we can produce it together. Thus, the traditional hierarchy between 
research and participant-as-researcher (for example, co-researcher) can be dismantled and revised into a space where all knowledge is valued and heard. The purpose of this article is to share our reflections on engaging youth, their experiences and their perspectives on the multilevels of impact of PAR methodologies, such as communitybased action research (CBA) or youth participatory action research (YPAR).

As we compare our two research projects, our intention is to share ways of applying a co-researcher model that offers a practical, credible and ethical PAR for research with youth. While different in context, we hope these two research projects show how participants help create research questions, collect data, analyse the data, determine what is of value and disseminate findings (Anyon et al., 2018). We believe that if co-researchers are contributing their knowledge to the research, their names need to be included in the byline of conference papers and academic journals. Co-researchers play an active role in contributing to writing, editing and making suggestions, as they did here.

This article draws largely from our past field research, where the first author, Staci, worked alongside co-researchers from Kakuma Refugee Camp, Kenya, and the second author, Jessica, worked alongside co-researchers from an alternative high school in the USA. The other two co-authors are co-researchers from Jessica's research; they were asked to be thought partners with us and provide insider perspectives. We all read and edited this article together.

In this article we discuss broadly how our PAR methodologies have impacted our co-researchers and ourselves. In it, we provide additional details about our past research projects while theorizing how critical theory serves as a tool within PAR. We reflect on the experiences engaging PAR in two different contexts and examine the collective impacts, comparing and contrasting the findings. In the next section, we provide background information on our respective studies.

\section{Background}

PAR methodologies support vulnerable communities to authentically contribute their voices and solutions to complex problems that impact them. Although our research centres on different populations, they share similar struggles of being seen as 'pushed out' by society and are often seen as a burden to society. If we are able to listen closely we can hear how they are contributing to the economy, educational system and creation of knowledge. The term pushout most often refers to youth who leave school before graduating because of people or circumstances inside the school (Tuck, 2012). In this article, the term is being used more broadly to refer to youth who have been pushed out to the margins by larger societal forces and systems of power and privilege. Foundational to both of the studies is the belief that understanding more about the perspectives and experiences of pushed out youth can lead educators and policymakers toward solutions that will create a more just and equitable education system (Chou et al., 2015). We start with Staci's research background.

\section{Refugee camp context}

Kakuma Refugee Camp was started in 1992 and is situated in the north-western region of Kenya. Demographic characteristics of Staci's sample are represented in Tables 1, 2 and 3. 
Table 1: Socio-demographics characteristics

\begin{tabular}{lcc}
\hline Socio-demographic characteristics & $\begin{array}{c}\text { Participants } \\
(\boldsymbol{n}=\mathbf{3 1})\end{array}$ & (\%) \\
\hline Age & 7 & 22.58 \\
18-24 & 14 & 45.16 \\
$25-30$ & 6 & 19.35 \\
$31-5$ & 4 & 12.90 \\
$36+$ & & \\
Gender & 9 & 29.03 \\
$\quad$ Female & 22 & 70.97 \\
Male & & \\
Relationship & 11 & 35.48 \\
$\quad$ Married & 20 & 64.52 \\
Single & & \\
Income & 8 & 25.81 \\
Unemployed & 11 & 35.48 \\
Private Services & 4 & 12.90 \\
Public Services & 4 & 12.90 \\
Other & 4 & 12.90 \\
$\quad$ Missing & & \\
\hline
\end{tabular}

Table 2: Demographic Characteristics of Sample (Refugee camp)

\begin{tabular}{lcr}
\hline Socio-demographic characteristics & $\begin{array}{c}\text { Participants } \\
(\boldsymbol{n}=\mathbf{3 1})\end{array}$ & $(\%)$ \\
\hline Ethnicity & 5 & 16.13 \\
Burundi & 5 & 16.13 \\
DRC & 1 & 3.23 \\
Ethiopia & 1 & 3.23 \\
Rwanda & 4 & 12.90 \\
Somalia & 9 & 29.03 \\
South Sudan & 5 & 16.13 \\
Sudan & 1 & 3.23 \\
Uganda & & \\
Religion & 11 & 35.48 \\
Catholic & 10 & 32.26 \\
Protestant & 8 & 25.81 \\
Muslim & 1 & 3.23 \\
Fill in the blank & 1 & 3.23 \\
Missing & & \\
Refugee & 31 & 100.00 \\
Yes & 0 & 0.00 \\
No & & \\
Kakuma & 31 & 100.00 \\
Yes & 0 & 0.00 \\
No & & \\
Length of Stay in Kakuma & 2 & 6.45 \\
Less than 12 months & 11 & 35.48 \\
Less than 5 years & 17 & 3.84 \\
Always & 1 & \\
Missing & & \\
\hline & & \\
\hline
\end{tabular}


Table 3: Demographic Characteristics of Sample (Refugee camp)

\begin{tabular}{lcr}
\hline Education Demographic Characteristics & $\begin{array}{c}\text { Participants } \\
(\mathbf{n}=\mathbf{3 1})\end{array}$ & (\%) \\
\hline Education & 2 & 6.45 \\
$\quad$ Primary Education & 9 & 29.03 \\
Secondary Education & 19 & 61.29 \\
Diploma & 2 & 6.45 \\
Bachelor & 1 & 3.23 \\
Master & 1 & 3.23 \\
Missing & & \\
School & & 100.00 \\
Jesuit Worldwide Learning: & 31 & 0.00 \\
$\quad$ Higher Education at the Margins & 0 & \\
Kenyatta University & & 61.29 \\
Languages Spoken & 19 & 12.90 \\
Two languages & 4 & 25.81 \\
Three languages & 8 & \\
Four+ languages & & \\
\hline
\end{tabular}

Owing to the practical aspects, Staci's partner organization suggested that she recruit participants from existing cohorts. Using a convenience sampling, 31 participants were recruited from Kakuma to participate in a survey (pre-, post- and follow-up), semistructured interviews and a psychosocial peacebuilding education course (PPBE). Figure 1 shows the core elements of the course: book-making/journalling, doll-making, story-making/story-telling and co-creating solutions.

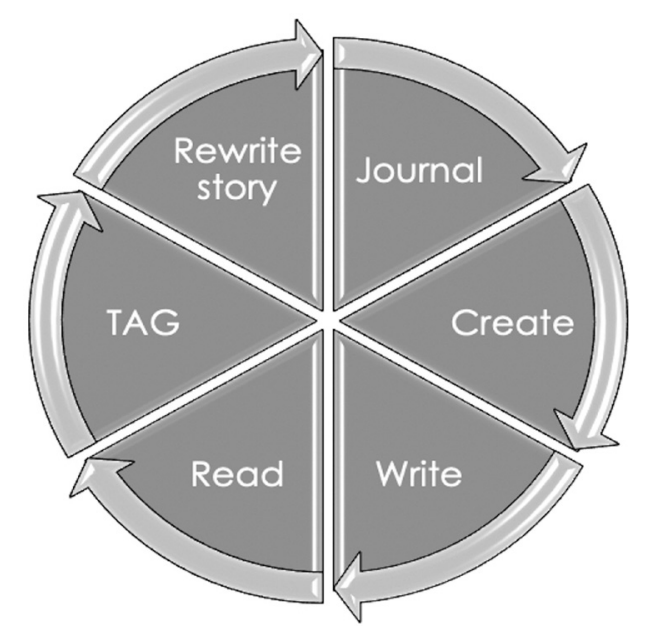

Figure 1. Psychosocial peace-building education course (Martin et al., 2018)

Out of the 31 participants, only six participants chose to be co-researchers and implement the PPBE course in their respective communities. Co-researchers were asked to reflect on what they observed, the dialogue in the sessions and any insights they had. All the co-researchers believed education was the key link for peace and that they could be a source of hope for others in the camp. A South Sudanese explained it this way: 'Someone who is educated will not hold a gun and go and fight. If we are not 
allowed to be educated this is a tool to kill ourselves. I will use it [education] as a tool to bring peace for young people, mostly for the youth' (Tesifa, 8 June 2017).

\section{Alternative high school context}

Alternative high schoolers can also be in limbo as they wait and navigate the educational system. Often labelled as 'dropouts', most young people at alternative schools have stories about how the mainstream school system pushed them out by failing to meet critical needs and/or by asking them to assimilate to a one-size-fits-all model based on white, middle-class values. The urban alternative high school at the heart of Jessica's study serves 17-24-year-olds through a model that includes: (1) high school graduation through a diploma or General Education Diploma [for example, a High School Equivalency Certificate], (2) the acquisition of valuable vocational skills in construction or technology, and (3) ongoing, long-term career coaching with the goal of placing young people in post-secondary education and living wage careers. A typical student at the alternative school has been out of school for two years and has experienced or is currently experiencing instability or trauma outside school. Demographic characteristics of Jessica's sample are represented in Tables 4 and 5 .

Table 4: Demographic characteristics of co-researchers (alternative high school)

\begin{tabular}{|c|c|c|c|c|}
\hline Name & Age & Gender & Race/Ethnicity & $\begin{array}{c}\text { Amount of Time } \\
\text { Participated as } \\
\text { Co-researcher }\end{array}$ \\
\hline Bee & 19 & Female & Latina & 4 months \\
\hline Irisa & 18 & Female & $\begin{array}{c}\text { Latina and } \\
\text { African American }\end{array}$ & $\begin{array}{l}\text { Ongoing } \\
\text { (about } 1 \text { year) }\end{array}$ \\
\hline Lulis & 18 & Female & Latina & $\begin{array}{c}\text { Ongoing } \\
\text { (about } 1 \text { year) }\end{array}$ \\
\hline Maria & 20 & Female & Latina & 8 months \\
\hline Shania & 19 & Female & Native American & 4 months \\
\hline Sk8 (Nash) & 23 & Male & African American & 8 months \\
\hline
\end{tabular}

Table 5: Demographic characteristics of student participants (alternative high school)

\begin{tabular}{ccccc}
\hline $\begin{array}{c}\text { Name } \\
\text { (Pseudonym) }\end{array}$ & Age & Gender & Race/Ethnicity & $\begin{array}{c}\text { Length of Time at } \\
\text { Alternative School }\end{array}$ \\
\hline $\begin{array}{c}\text { Ame } \\
\text { Friday }\end{array}$ & 18 & Female & White & 8 months \\
Manny & 18 & Female & White & 7 months \\
Martin & 18 & Male & Latino & 8 months \\
Olivia & 18 & Memale & Native American & 5 months \\
Peter & 18 & Male & African American & 7 months \\
Ricky & 18 & Gender Fluid & White & 6 months \\
Xavier & 21 & Male & African & 1 year \\
& & &
\end{tabular}

All students at the alternative school were offered the opportunity to take an elective class called Action Research, and all students who joined the class were recruited as co-researchers. One co-researcher, Lulis, said she joined because 'My goal is to 
make an impact' (Lulis Lares Benitez, researcher notebook, 28 March 2017). Most co-researchers said they felt their perspectives mattered and they wanted to help change the education system to make it better for future young people.

\section{Action research and PAR methodologies}

Before we broadly discuss how our PAR has impacted our co-researchers and ourselves, we define action research and other PAR methodologies. Reason and Bradbury (2001) note that action research is based on reflection and understanding, and that without action the research could be seen as empty and meaningless. Thus, the goal of PAR is to research with (not on) participants by involving them as co-researchers, positioning them as authorities of their own experiences and further developing their awareness of systemic issues to move them to social action (Cammarota and Fine, 2008; Burbach, et al., 2017; Martin, et al., 2018). In other research, youth are generally the objects of research - observed, surveyed, measured and commented upon - with little to no power in the research process and no voice in deciding the key findings (GroundwaterSmith and Downes, 1999). In contrast, PAR is a methodological tool for research in which youth are partners and key interpreters throughout the research process (Gerstein, 2010). We later illustrate in our results section how we co-created spaces with youth to foreground their voices in analysing and determining the implications of the research in their lives.

In the past decade, PAR methodologies have been readily applied, 'however, how much the community or individual actually participate in the research is unknown unless the researcher explicitly notes it' (Martin and Umubyeyi, 2019: 123). There are limited studies involving research with youth in protracted and emergency contexts (Pittaway et al., 2010) and alternative education contexts (lachini et al., 2013; LaganaRiordan et al., 2011; Schwartz, 2014). Research from youth's own perspectives and voices is largely absent from the literature. We have found only a few examples (Chou et al., 2015; Tuck, 2012) of youth involvement in taking action as a result of the findings of these studies. At the heart of PAR, it is not enough just to research with youth; it must have some action that affirms their sense of agency to use this knowledge to make changes in their lives (Guba and Lincoln, 2005). Too often 'research may be seen as benefiting the lives and careers of researchers, but leaving the lives of those being researched unimproved in any significant way, regardless of the time, energy and resources they have contributed to the research effort' (Sukarieh and Tannock, 2013: 4). In contrast, we are attempting to have youth collaborating with us at every step of the way, including data collection, analysis process, presenting and publishing.

While employing PAR, we were guided by conceptual frameworks. Staci applied a critical hope (Duncan-Andrade, 2009; Zembylas, 2014) conceptual framework; that is, the 'pedagogical tool that uses a critical theory lens to address unjust systems through meaningful dialogue and empathic responses' (Martin, 2018: 30). Jessica employed a framework combining approaches from critical pedagogy (Freire, 1970), decolonizing research methodology (Smith, 2012) and social justice research methodology (Pizarro, 1999). Her research centred on the knowledge and worldviews of youth at the alternative school, youth had authority in the data collection and analysis process, and together they co-created space to authentically represent their experiences within education research. 
We wanted our research to strengthen communities and/or be subversive rather than control, marginalize and silence voices. We strongly link PAR as a tool for critical theory because we believe that to disrupt the marginalization of communities we need research that is done by those communities and is for their purposes. In the next section, we share our methodology and approach.

\section{Methods}

Both our studies partnered with youth and positioned them as co-researchers. Co-researching means that youth participants are involved throughout the research process as investigators and together co-construct the findings and implications based on the data collected. Bee, one of the youth co-researchers, described her experience as a co-researcher. She stated: 'Being with other students not just with other adults ... we were in charge ... it was really awesome to talk to students and have them trust us because they realized that we had been through a lot of the same stuff as they had' (Bee, interview, 13 June 2017).

Bee emphasized three important aspects of being a co-researcher: (1) youth leadership in the research process, (2) easily building trust with the student participants because of their shared experiences, and (3) the empowerment of working on a project in solidarity with peers. Another co-researcher, Tesifa, spoke about being in solidarity with the community: 'I realized through sharing the experiences that other people have gone through similar experiences and I did not try to confine myself in my own situation ... And that is how we go about our change' (Tesifa, interview, 8 June 2017).

Tesifa's quote exemplifies what Lave and Wenger (1991) call co-researchers and researchers' 'communities of practice', which refers to groups of people collectively learning around a shared purpose. While researchers bring important knowledge, skills and resources to the project, they may miss key insights or interpretations because of their outsider lens. Positioning youth as co-researchers values the insider knowledge and practices that they bring from the community at the centre of the research. Although both Staci and Jessica used PAR, their exact methods for data collection and analysis, use of co-researching and approaches to taking action were unique.

\section{Refugee camp context}

In one study, first author Staci utilized a pragmatic dual track, mixed methods researchintervention process model (Morgan, 2014; Nastasi et al., 2007), which applied a CBA approach (Openjuru et al., 2015; Reason and Bradbury, 2001). Staci used the Hope Index of Staats (1989) survey (pre-, post- and follow-up), semi-structured interviews and PPBE course. The course served as an intervention.

A CBA approach was applied in the implementation of the course. Thirty PPBE courses were facilitated within the co-researchers' communities, three schools, two non-governmental organizations and one government agency. Co-researchers and Staci's research logs served as the collected data. Our aim was 'to explore the ways refugee youth in a higher education protracted context can become producers of research and knowledge' (Martin et al., 2018: 140). Our research questions were:

(1) How do we co-create spaces of hope in refugee camps that are supposed to be temporary in theory, yet in practice are often permanent?

(2) In between moments of waiting for something to happen, how do we support youth who are refugees in remaining hopeful? (ibid.) 
We used a research process that had three phases: assess, act and wonder (refer to Figure 2).

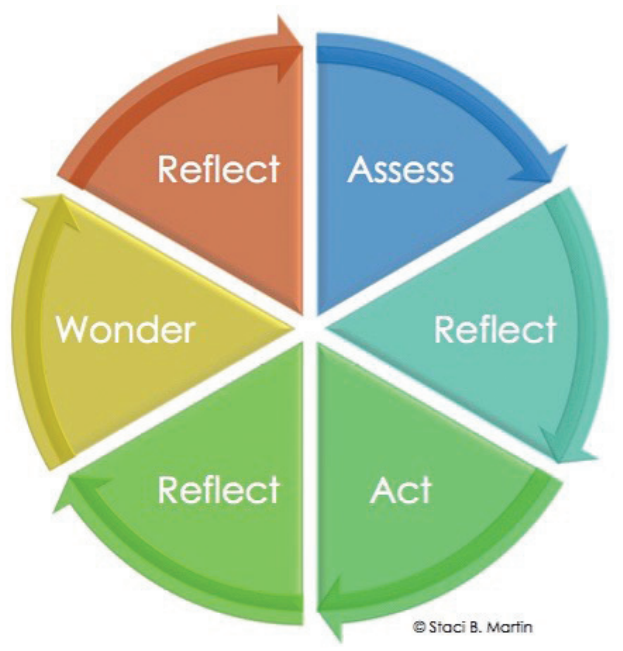

Figure 2. CBA process (Martin et al., 2018)

Concurrently after each phase, we reflected. The assess phase offered context of the evolving situation. The act phase was the PBBE intervention and the wonder phase was our reflections of what was learned in each session. Each reflection phase made the programme more culture specific as the co-researchers would add their own approach and insight. As we coded our data, we came up with three strands: time, place and person. The time and place strands focused on where and how PPBE participants found hope and/or remained hopeful, while the person strand focused on co-researchers as agents of change (Martin et al., 2018). As a result, a peer-reviewed academic paper was co-written with co-researchers about their experiences that integrated all five home languages (ibid.).

\section{Alternative high school context}

Second author, Jessica, did research with students (ages 18-23 years) at an alternative high school using a YPAR approach, in which youth co-researchers helped collect and analyse the data and then acted based on their findings. The purpose of the study was to explore the educational experiences of youth at an alternative school. Six co-researchers and Jessica interviewed eight student participants across multiple interviews, focused on three main topics: (1) their experiences at the alternative school, (2) their experiences at their previous schools, and (3) what needs to change about the education system. To analyse the data, Jessica and the co-researchers met each week to discuss what was significant to them in the interviews, what they saw as emerging themes and how their own educational experiences fitted with what they heard.

Following Freire's (1970) model of problem-posing education, the co-researchers identified 'generative' themes in the interview data and synthesized those findings into recommendations for changes to the education system. The goal of this process was to authentically involve and centre the perspectives of youth who had been most directly impacted by the issue of school pushout (Irizarry and Brown, 2014; Pizarro, 1999).

To take action in response to their findings, Jessica and the co-researchers shared their recommendations for changing the education system at multiple presentations, 
including (1) graduating teacher candidates at a local university, (2) staff and students at the alternative school, and (3) at two conferences. By sharing the experiences of youth who had left school, they sought to transform the knowledge and practices of teachers and improve the educational experiences of current and future youth (Rodríguez and Brown, 2009). In these presentations, the co-researchers spoke truth to power and challenged the dominant view of what it means to be a 'dropout' in spaces where their voices are rarely heard. Taking action through these papers and presentations deeply impacted both Staci and Jessica and their co-researchers, which we discuss in the next section.

\section{Results: Impacts}

In reflective discussions with ourselves and co-researchers, we found that coresearching had impacted us in different ways. Our co-researchers noted that they began to see themselves differently as they got more involved in analysis, writing and presenting. As researchers, we also saw ourselves changing as we worked alongside them. We drew from our own past collaborative work with co-researchers to discuss the impact of applying a participatory methodology on the co-researchers, on ourselves as researchers and on the dominant narrative of pushouts.

\section{Impact on Staci's participant co-researchers}

In a recent paper, Martin and Umubyeyi (2019: 124), Staci's co-researcher, explained how co-researching changed how she saw herself:

Co-researching increased my self-confidence because I did something valuable for my community. Whenever I saw researchers, I always thought that they are the only ones meant to do research because they studied for that. I never thought that I can also contribute by doing research.

When refugees are displaced they are in a constant state of reconstruction of their lives. They are often dependent on many aid agencies (such as UNHCR, UNICEF), non-governmental organizations (NGOs), and governments. A PAR approach can support refugees in this reconstruction of self by acknowledging their inherent worth and expertise that extends outside their community to the academy.

In a conference paper, Martin and Teferra (2018), another co-researcher, explained how his expertise is needed:

I believe researchers often collect data and make analysis to prove their own truth, assumptions or perception. Or else, they write their research in a way that the outputs benefit themselves, their sponsor and employees. In effect, they bring what they can or have, but not what we need. The way they study and understand us may not be wrong, but incomplete and biased. I believe co-researching empowers us, creates opportunities to speak out for ourselves, and helps us see ourselves from different perspectives.

Through a PAR approach, knowledge can be created so that co-researchers are able to take actionable steps to dictate what sort of action they want, who is promoting that action, where the action is coming from and how that action will impact their communities (Brydon-Miller et al., 2003; Fine, 1994). 


\section{Impact on Jessica's participant co-researchers}

While it was often difficult for Jessica's co-researchers to listen to the students' stories of being pushed out, it also offered an empathetic space to process these shared experiences. For example, one co-researcher, Lulis (interview 11, 13 June 2017), said:

For me, it was mostly just acceptance like accepting that [it] did happen but there's nothing that I can change about it now. But then moving forward to actually do something so other students won't experience the same thing. So yeah, for me it's all about the acceptance ... what happened in high school, I just buried it ... And I feel if I didn't do this research, it would have come up another way and I wouldn't be with other people ... I would have lost my shit, you know ... I'm just really grateful that we're all here [at this alternative school].

For Lulis, part of the process of acceptance was taking action to prevent other young people from having negative educational experiences.

Other co-researchers mentioned how their motivation to stay in school and their feelings of self-worth were positively affected. For example, Irisa (interview 11, 13 June 2017) asserted, 'If I wouldn't have been co-researching and I [hadn't] come to you guys with my problems ... I could have stopped being here at [this alternative school]. I feel you guys [the co-researchers] keep me motivated to keep coming here'. Irisa's statement speaks to the trust that developed between the co-researchers, as well as their commitment to the research project and to each other.

Ultimately, the co-researchers stated that presenting their research findings was one of the most powerful experiences because they told their stories to folks in power. When asked how she knew that her voice was being heard at the presentations, Lulis (personal communication, 11 January 2018) said:

Seeing them take notes, taking pictures, everybody asking really good freaking questions. And I was like, 'Yes!' That's how I knew that we were being heard. I also got to talk to people individually and got to know them ... One lady dealt with kids with disabilities and didn't feel supported. I gave her our [contact information] and circled 'You are supported' on the back, saying 'I got you!'

When using PAR, the potential for co-researchers to be deeply and personally impacted should not be underestimated. These changes are not just felt by the co-researchers, but also by the researcher.

\section{Impact on researchers}

The use of PAR methodologies can mean that the researchers become deeply immersed, having impacts on their positionality and how they see themselves (Fine, 1994). We believe it is important to have multiple viewpoints - a more collaborative inquiry - to see what you are not noticing and perhaps what you are focusing on too much.

In Staci's past experiences, she counselled sexual assault survivors, counselled pre-adjudicated youth who had been accused of heinous crimes, lived and worked in post-conflict areas, but never simultaneously, in a brief amount of space, time and place. She was overwhelmed by the intensity, vividness and raw emotion of participants' stories of grief, hope and despair, while recognizing she chose to be there and would be there temporarily. 
Staci felt self-doubt, hopeless/hopeful and privileged. As a transracial Korean adoptee, she recognizes that holding an American passport comes with privilege, a lifeline, that all of her co-researchers may one day have or never have. Too often, she questioned herself why she was chosen to have that passport instead of anyone else. Living and researching in a refugee camp highlighted that there are systems that favour a dominant society at the expense of others. Staci was complicit in the system, as she had basic amenities in the camp, while recognizing that the co-researchers' food rations were reduced, floods were destroying homes and health services were limited. In order to disrupt this, she co-facilitated the course when co-researchers were ready, not vice versa. She followed the co-researchers' lead, and served as a third hand (Kramer, 1986) as the course was run in the co-researchers' home language. She believed it was not enough, but her experience drove her to provide more critical hope; that is, co-create more spaces for co-researchers to voice their concerns in their languages, in their context and with their voice in the forefront.

Turning to Jessica, we find that by working in solidarity with her co-researchers and those at the heart of the research study, she began to authentically empathize with the youth in the study, rather than taking a more distant, intellectual approach to the research. As a white, middle-class woman who had been successful in mainstream education, Jessica did not pretend to understand the traumatic school experiences that these young people described. And yet she was invited into the empathetic space co-created between the co-researchers and student participants in these interviews to feel alongside these young people and not just intellectualize and analyse their stories as data.

Jessica felt sad, angry, depressed, disturbed and overwhelmed by the stories of the student participants. She learned that emotional distance was not always an asset to this research project. The immersiveness of PAR built empathy between Jessica and the student participants and helped make the research more respectful and humanizing to those involved. For example, instead of being attached to the research plan, Jessica prioritized scheduling that would be most respectful to the student participants' needs and priorities.

Furthermore, we both found that our research has impacted more than just the co-researchers and ourselves. It has also disrupted some narratives that legitimize the dominant narratives (Peters and Lankshear, 1996).

\section{Impact on the dominant narrative}

Fine (1994) explains that we need to counter the narratives and write against othering. When the official narratives are presented, counternarratives need to be at the forefront. Counternarratives take into account the social and political contexts within which the dominant narrative is made (ibid.).

By applying a PAR approach, pertinent questions are asked about whose voices are heard in describing the refugees' experience and whose voices are absent. By creating spaces, places and access for individuals to speak for themselves via refugeeled courses (such as PPBE course), conferences (for example, Martin and Teferra, 2017, 2018; Martin and Umubyeyi, 2018), and academic papers (for example, Martin et al., 2018; Martin and Umubyeyi, 2019), refugee voices can be heard, seen and valued. While co-presenting or co-authoring may be seen as trivial, the reality is that few refugees living in refugee camps have these opportunities. We can offer a counternarrative to the academy if we have examples that show this is possible and the reviewers see the value of diversity of voices, languages and ideas. In the Martin and Umubyeyi (2019) paper, a peer-review remarked, 'It is refreshing to hear directly from Vestine [co-researcher] 
and the article lays out an important argument for the value of a community-based action approach' (A. Pacifico, email communication, 5 February 2019). The reviewer is showing critical hope. Furthermore, these counternarratives are creating spaces where co-researchers can talk with the people in the field who are often merely talking about their community.

When working in a PAR approach, refugee-led courses can make profound impacts within systems that are attempting to support them. Creating spaces to have meaningful dialogues allows both parties to question their complicity in maintaining the status quo. For example, Staci co-facilitated the PPBE course with a co-researcher to Kenya's Social Service Providers (SSP). There was a discussion of limited education scholarships, how difficult it was to decide who receives them and how that was the reason SSP didn't reply to queries. The co-researcher remarked that this gave refugees false hope. He didn't realize the SSP cared so much. Critical hope is seen when the SSP (personal communication, 15 March 2017) said, 'We need to question this thought of false hope and what our agency is really doing.'

Another example of an impact was when two co-researchers co-facilitated the PPBE course to staff from Kenya's Refugee Affairs Secretariat (RAS). Often RAS staff don't have the opportunity to see refugees leading, and in turn many refugees don't have access to lead. This was a shift in both their thinking. Two years after the course was facilitated, a participant explained how that course impacted the staff:
When it comes to how we treat refugees it's totally different from how we used to do it. There is a warm reception, we listen to them, and we have opened our gates to enable refugees to come to our office. In the community services, we have developed community fact sheets, these are tools to make us understand refugees. Before refugees used to elect leader's among their own, I mean from the same nationality, but last year December we did a general election for refugees where we formed regions end each region elected four leaders: chairperson, vice chair, youth representative and person with disability. This has really worked well as we have leaders across nationalities. This will assist in making refugees feel they are one end they can coexist. (N. Kaanto, personal communication, 10 July 2019)

PAR can provide the critical hope that pushes people forward in order to see they already have the expertise and solutions in front of them. We researchers may not see these impacts at all, but they may cause ripples that bring hope in the long run.

Turning to critical race theory and counternarratives, we find that for Jessica they were at the forefront of her findings. Using Solórzano and Yosso's (2009) critical race theory methodological framework, she and the co-researchers compiled eight counternarratives representing each student participant's educational experiences. The critical theory lens was crucial in creating the counternarratives because it helped them focus on the often-silenced voices from members of historically marginalized communities. More importantly, the co-researchers' involvement in creating these counternarratives meant that youth from these marginalized communities had power over how their stories were told. The final presentation of the counternarratives was informed by: (1) the discussions the co-researchers and Jessica had about what was significant throughout the data collection and analysis process, and (2) a member checking with the student participants who read and made changes to how the counternarratives represented their experiences. Hence, PAR methodologies deepened the use of critical theory by going beyond simply pointing out inequities 
in power and privilege, and actually disrupting them. The researched became the researchers and the previously silenced youth had control over the narrative.

While each of the eight counternarratives are unique, the co-researchers and Jessica co-constructed four themes that they saw across these counternarratives and in their own experiences: (1) 'I felt invisible to the teachers', (2) 'Teaching is a sacred act', (3) 'Regular high school is like drowning, it's cruel', and (4) 'Dropping out was [actually] a success'. These themes challenged the dominant dropout narrative, which paints a picture of youth who drop out because they are lazy, unmotivated and make poor life choices. In contrast, the counternarratives speak to how the decision to leave school can be seen as a positive, healthy choice to escape dehumanizing and intolerable school experiences. They learned that when students leave school it says much more about what their mainstream schools are doing or not doing that is negatively impacting students than about who these young people are and what they can do. Hence, the counternarratives challenged the dominant narrative and asked us to be more critical of what schools, administrators and teachers are doing to push out youth.

\section{Implications}

\section{Cross-cutting implications}

As academic researchers engaged in PAR, we address the intended and unintended implications of these approaches. While other studies may be concerned with objectivity and the ability to generalize findings, often PAR studies are focused on depth by collecting rich data from several perspectives to reveal how a specific population describes their experiences. PAR is intended to interrupt positivist research practices done in the name of objectivity that 'others' participants and treats them as objects. Cleaver (1999) noted that there is limited evidence of long-term effectiveness of PAR. Although written two decades ago, her astute commentary doesn't necessarily devalue PAR. Rather it asks researchers to interrogate the intended and unintended impacts of participatory method approaches.

\section{Intended implications}

PAR intends to affirm that research has a responsibility to act 'upon (or renam[e]) the world to make it a more just, equitable, and humane place to inhabit' (Mirra, et al., 2016: 23). PAR pushes on traditional ways of doing research and may cause entrenched assumptions about the capabilities of vulnerable communities to rise to the surface. Young people are researchers and changemakers and, therefore, the field of education research should not underestimate their ability to advocate for what they need and contribute to the ethics of a research study. For example, the PPBE was implemented where the refugees wanted it to be implemented (for example, afterschool programmes, vocational programme, teacher trainings, NGOs, Refugee Affairs Secretariat). They adapted the PPBE to their own style and vision and called it the Sunrise project. Similarly, the alternative school changed their hiring practices as well as their class schedule and curriculum to address the recommendations from the co-researchers and Jessica based on their research. 


\section{Unintended implications}

PAR's unintended consequences could result in researchers offering manufactured hope; that is, an external action that is built to prop up a hope that will never truly exist (Martin, 2018). PAR often intends to dismantle unjust systems (such as education and immigration). However, what may happen is there are only incremental impacts to the system that result in little significance to the co-researchers who are living in a situation (Sukarieh and Tannock, 2013). In order to counter manufactured hope, critical hope could be integrated. Critical hope is a hope with action that is dictated by and for the individual in the context. Both Staci and Jessica believe this kind of hope can be generated through PAR with actionable results.

Researchers may also have some unintended benefits that they didn't realize were possible before they started. For example, Jessica recently made a new hire because of a conference presentation done with her co-researchers. The teacher of colour remarked that she sought out the job because of what the co-researchers said they needed, more teachers of colour in their alternative high school. To take another example, Staci integrated co-researchers' voices in a section of an online course where participants are refugees themselves from Rwanda, Kenya and Jordan refugee camps. Co-researchers received acknowledgement of their own worth, knowledge and skills from their peers. In this course they also had space to question what is presently happening (for example, conditions of camp, limited education) and reinforcing their own worth, knowledge and skills.

Overall, PAR can be an asset to education research. Studies such as ours are evidence that involving vulnerable communities who have lived experiences in their respective communities can have a significant impact on educational policy. When Jessica's co-researchers shared their themes and findings with the alternative school, they made a very specific recommendation for change at the school: to provide more support for young women in the programme. Since the presentation, the school has modified their hiring policy to diversify their staff so that it reflects the student body.

\section{Conclusion}

This article discusses how our participatory methodologies have impacted our coresearchers and ourselves. In it we have provided additional details about our past research projects, as well as theorizing those details in terms of how critical theory serves as a tool within participatory methodologies. For participants and co-researchers in our contexts, education is often seen as a beacon of hope. PAR challenges the traditional ways in which research presents data, reaching readers and contributing to knowledge construction in ways that might not otherwise happen (Hubain et al., 2016). This results in counternarratives that create space for youth voice, experience and knowledge to enter into dominant educational research, speak truth to power and potentiate change in education.

\section{Acknowledgements}

We would like to acknowledge our respective communities, Kakuma Refugee Camp community and Portland YouthBuilders, that trusted us to do our research with, for and led by them; as well as Drs Dannelle D. Stevens and Swapna Mukhopadhyay, chairs of our dissertation committees, who mentored, trusted and supported us through our seminal research. We would also like to acknowledge our anonymous peer-reviewers, 
as they offered invaluable feedback that in turn brought clarity and organization to this work.

\section{Notes on the contributors}

Staci B. Martin, EdD, is a faculty member of Portland State University's School of Social Work. Her research and teaching are critical hope and despair, refugee education, psychosocial, peace-building and participants as co-researchers. Her experiences include designing, implementing and evaluating psychosocial peace building educational programmes in South Africa, Nepal, Jamaica and Kenya. She was the recipient of the 2018 Carnegie Project of the Education Doctorate (CPED) Dissertation in Practice of the Year Award.

Jessica H. Burbach, EdD, is Education Manager at an alternative school, Portland YouthBuilders, where she previously taught mathematics for nearly ten years. Jessica has explored teaching mathematics through social justice issues and has presented her lessons with students at various conferences. In 2018, she completed her doctorate of education in educational leadership. Using YPAR, her dissertation focused on the educational experiences of youth who have been pushed out of school.

Lulis Lares Benitez is a graduate of Portland YouthBuilders and was a co-researcher with Jessica on a project to interview youth about their educational experiences. Her family is her motivation and her dream is to be an entrepreneur and to start her own business. She is currently working at a school for youth with autism and is considering a career in education.

Irisa Ramiz is a graduate of Portland YouthBuilders and was a co-researcher with Jessica on a project to interview youth about their educational experiences. She is also a talented singer and hopes to be a nurse and mentor to young people in the future.

\section{References}

Anyon, Y., Bender, K., Kennedy, H. and Dechants, J. (2018) 'A systematic review of youth participatory action research (YPAR) in the United States: Methodologies, youth outcomes, and future directions'. Health Education and Behavior, 45 (6), 865-78.

Bengtsson, S. and Bartlett, L. (2011) 'From child-friendly schools to child-friendly research methods: Lessons learned on child-centered research from UNICEF's Learning Plus Initiative'. In Mundy, K. and Dryden-Peterson, S. (eds) Educating Children in Conflict Zones: Research, policy, and practice for systemic change: A tribute to Jackie Kirk. New York: Teachers College Press, 235-53.

Brydon-Miller, M., Greenwood, D. and Maguire, P. (2003) 'Why action research?'. Action Research, 1 (1), 9-28.

Burbach, J., Martin, S.B., Arnold-Fowlkes, J., Escobedo, M., Hibbs, A., Julius, C., Musgrove, C. and Sakaith, J. (2017) 'Who defines me? Spaces and places of agency and hope'. In Keengwe, J. (ed.) Handbook of Research on Promoting Cross-Cultural Competence and Social Justice in Teacher Education. Hershey, PA: IGI Global, 178-92.

Cammarota, J. and Fine, M. (2008) 'Youth participatory action research: A pedagogy for transformational resistance'. In Cammarota, J. and Fine, M. (eds) Revolutionizing Education: Youth participatory action research in motion. New York: Routledge, 1-12.

Castleden, H., Sloan Morgan, V. and Lamb, C. (2012) '“I spent the first year drinking tea": Exploring Canadian university researchers' perspectives on community-based participatory research involving Indigenous peoples'. Canadian Geographer, 56 (2), 160-79.

Chou, F., Kwee, J., Lees, R., Firth, K., Florence, J., Harms, J., Raber, M., Stevens, T., Tatomir, R., Weaver, C. and Wilson, S. (2015) 'Nothing about us without us! Youth-led solutions to improve high school completion rates'. Educational Action Research, 23 (3), 436-59.

Cleaver, F. (1999) 'Paradoxes of participation: Questioning participatory approaches to development'. Journal of International Development, 11 (4), 597-612. 
Duncan-Andrade, J.M.R. (2009) 'Note to educators: Hope required when growing roses in concrete'. Harvard Educational Review, 79 (2), 181-94.

Fenge, L.-A., Fannin, A. and Hicks, C. (2011) 'Co-production in scholarly activity: Valuing the social capital of lay people and volunteers'. Journal of Social Work, 12 (5), 545-59.

Fine, M. (1994) 'Working the hyphens: Reinventing self and other in qualitative research'. In Denzin, N.K. and Lincoln, Y.S. (eds) Handbook of Qualitative Research. Thousand Oaks, CA: SAGE Publications, 70-82.

Freire, P. (1970) Pedagogy of the Oppressed. Trans. Ramos, M.B. New York: Continuum.

Gerstein, J. (2010) 'Youth participatory action research (YPAR)'. User Generated Education blog, 3 August. Online. https://tinyurl.com/yyvdoh4v (accessed 1 August 2019).

Groundwater-Smith, S. and Downes, T. (1999) 'Students: From informants to co-researchers'. Paper presented at the Australian Association for Research in Education (AARE) Annual Conference, Melbourne, 29 November-2 December 1999.

Guba, E.G. and Lincoln, Y.S. (2005) 'Paradigmatic controversies, contradictions, and emerging confluences'. In Denzin, N.K. and Lincoln, Y.S. (eds) The SAGE Handbook of Qualitative Research. 3rd ed. Thousand Oaks, CA: SAGE Publications, 191-215.

Hubain, B.S., Allen, E.L., Harris, J.C. and Linder, C. (2016) 'Counter-stories as representations of the racialized experiences of students of color in higher education and student affairs graduate preparation programs'. International Journal of Qualitative Studies in Education, 29 (7), 946-63.

lachini, A.L., Buettner, C., Anderson-Butcher, D. and Reno, R. (2013) 'Exploring students' perceptions of academic disengagement and reengagement in a dropout recovery charter school setting'. Children and Schools, 35 (2), 113-20.

Irizarry, J.G. and Brown, T.M. (2014) 'Humanizing research in dehumanizing spaces: The challenges and opportunities of conducting participatory action research with youth in schools'. In Paris, D. and Winn, M.T. (eds) Humanizing Research: Decolonizing qualitative inquiry with youth and communities. Thousand Oaks, CA: SAGE Publications, 63-80.

Kramer, E. (1986) 'The art therapist's third hand: Reflections on art, art therapy, and society at large'. American Journal of Art Therapy, 24 (3), 71-86.

Lagana-Riordan, C., Aguilar, J.P., Franklin, C., Streeter, C.L., Kim, J.S., Tripodi, S.J. and Hopson, L.M. (2011) 'At-risk students' perceptions of traditional schools and a solution-focused public alternative school'. Preventing School Failure, 55 (3), 105-14.

Lave, J. and Wenger, E. (1991) Situated Learning: Legitimate peripheral participation. Cambridge: Cambridge University Press.

Martin, S.B. (2018) 'Co-Creating Spaces of Critical Hope through the Use of a Psychosocial Peace Building Education Course in Higher Education in Protracted Refugee Context: Kakuma Refugee Camp, Kenya'. Unpublished EdD thesis, Portland State University.

Martin, S.B. and Teferra, G. (2017) 'Whose knowledge is valued and why?'. Poster presentation at the Inter-Agency Network for Education in Emergencies (INEE) Round Table on Psychosocial Support and Social and Emotional Learning, Florence, 18 October 2017.

Martin, S.B. and Teferra, G. (2018) 'Hope disrupted: Refugees in limbo'. Paper presented at the Konferenz des Netzwerks Flüchtlingsforschung (Conference of the Refugee Research Network), Catholic University Eichstätt-Ingolstadt, Munich, 4-6 October 2018.

Martin, S.B. and Umubyeyi, V. (2018) 'Art-making, story-making, and finding solutions: Psychosocial peace-building education'. Master Class/Course at the Creative Arts Therapies Conference, Marylhurst University, 20-22 April 2018.

Martin, S.B. and Umubyeyi, V.L. (2019) 'What works in education in emergencies: Co-researching and co-authoring'. NORRAG Special Issue, 2, 122-5.

Martin, S.B., Warsame, D.I., Bigirimana, C., Lajustine, V.U., Teferra, G., Abdi, A.S. and Taban, J.O. (2018) 'Kakuma Refugee Camp: Where knowledge and hope resides'. In Sengupta, E. and Blessinger, P. (eds) Refugee Education: Integration and acceptance of refugees in mainstream society (Innovations in Higher Education Teaching and Learning 11). Bingley: Emerald Publishing, 139-55.

Mirra, N., Garcia, A. and Morrell, E. (2016) Doing Youth Participatory Action Research: Transforming inquiry with researchers, educators, and students. New York: Routledge.

Morgan, D.L. (2014) Integrating Qualitative and Quantitative Methods: A pragmatic approach. Thousand Oaks, CA: SAGE Publications.

Nastasi, B.K., Hitchcock, J., Sarkar, S., Burkholder, G., Varjas, K. and Jayasena, A. (2007) 'Mixed methods in intervention research: Theory to adaptation'. Journal of Mixed Methods Research, 1 (2), 164-82. 
Openjuru, G.L., Jaitli, N., Tandon, R. and Hall, B. (2015) 'Despite knowledge democracy and community-based participatory action research: Voices from the global south and excluded north still missing'. Action Research, 13 (3), 219-29.

Peters, M. and Lankshear, C. (1996) 'Postmodern counternarratives'. In Giroux, H., Lankshear, C., McLaren, P. and Peters, M. Counternarratives: Cultural studies and critical pedagogies in postmodern spaces. New York: Routledge, 1-39.

Pittaway, E., Bartolomei, L. and Hugman, R. (2010) "'Stop stealing our stories": The ethics of research with vulnerable groups'. Journal of Human Rights Practice, 2 (2), 229-51.

Pizarro, M. (1999) '" ¡Adelante!": Toward social justice and empowerment in Chicana/o communities and Chicana/o studies'. In Parker, L., Deyhle, D. and Villenas, S. (eds) Race Is... Race Isn't: Critical race theory and qualitative studies in education. Boulder, CO: Westview Press, 53-81.

Reason, P. and Bradbury, H. (eds) (2001) Handbook of Action Research: Participative inquiry and practice. London: SAGE Publications.

Rodríguez, L.F. and Brown, T.M. (2009) 'From voice to agency: Guiding principles for participatory action research with youth'. New Directions for Youth Development, 123, $19-34$.

Schwartz, J. (2014) 'Classrooms of spatial justice: Counter-spaces and young men of color in a GED program'. Adult Education Quarterly, 64 (2), 110-27.

Smith, L.T. (2012) Decolonizing Methodologies: Research and indigenous peoples. 2nd ed. London: Zed Books.

Solórzano, D.G. and Yosso, T.J. (2009) 'Critical race methodology: Counter-storytelling as an analytical framework for educational research'. In Taylor, E., Gillborn, D. and Ladson-Billings, G. (eds) Foundations of Critical Race Theory in Education. New York: Routledge, 131-47.

Staats, S. (1989) 'Hope: A comparison of two self-report measures for adults'. Journal of Personality Assessment, 53 (2), 366-75.

Sukarieh, M. and Tannock, S. (2013) 'On the problem of over-researched communities: The case of the Shatila Palestinian refugee camp in Lebanon'. Sociology, 47 (3), 494-508.

Tuck, E. (2012) Urban Youth and School Pushout: Gateways, get-aways, and the GED. New York: Routledge.

Zembylas, M. (2014) 'Affective, political and ethical sensibilities in pedagogies of critical hope: Exploring the notion of "critical emotional praxis"'. In Bozalek, V., Leibowitz, B., Carolissen, R. and Boler, M. (eds) Discerning Critical Hope in Educational Practices. London: Routledge, 11-25. 